\title{
Liberdade e democracia em conflito
}

\author{
Freedom and democracy in conflict
}

\author{
ERICSON SÁVIO FALABRETTI (D)a
}

\section{Resumo}

A experiência democrática moderna indica que o nosso sistema político mantém uma relação de sobredeterminação com a liberdade. Toda forma de sistema político determina o alcance e o sentido da nossa liberdade, ao mesmo tempo em que a experiência concreta de liberdade modifica o sistema político. Sustentamos neste trabalho que a liberdade individual elevada ao princípio máximo de realização existencial e à consagração ideal de vida política é, ao mesmo tempo, o registro jurídico-político de que realmente vivemos em uma democracia, sem, contudo, deixar de se apresentar como força desestruturante do próprio regime democrático.

Palavras-chaves: Democracia. Liberdade. Política. Rousseau. Rancière.

\begin{abstract}
The modern democratic experience indicates that our political system maintains an overdetermination with freedom. Every form of political system determines the scope and meaning of our freedom, while the concrete experience of freedom changes the political system. We affirm in this work that individual freedom elevated to the maximum principle of existential realization and the ideal consecration of political life is, at the same time, the legal-political record that we really live in a democracy, however, presenting itself as a destructuring force in the democratic regime.
\end{abstract}

Keywords: Democracy. Freedom. Politics. Rousseau. Rancière.

\footnotetext{
a Pontifícia Universidade Católica do Paraná (PUCPR), Curitiba, PR, Brasil. Doutor em Filosofia, e-mail: ericson.falabretti@pucpr.br
} 


\section{Introdução}

A nossa recente experiência democrática nas últimas três décadas ${ }^{1}$ parece indicar que a democracia está encerrada em uma crise perpétua relacionada aos seus dois primeiros fundamentos. Em primeiro lugar, a liberdade individual elevada ao princípio máximo de realização existencial e à consagração ideal de vida política é, ao mesmo tempo, o registro jurídico-político de que realmente vivemos em uma democracia, sem, contudo, deixar de se apresentar como força desestruturante do próprio regime. Em segundo lugar, apesar de todas as lutas por direitos civis e da ampliação dos Direitos Humanos para os direitos de segunda, terceira e quarta geração, a experiência democrática abarca um contínuo processo de normalização da desigualdade real nas suas mais diferentes expressões concretas, seja pela negação das demandas por lutas identitárias, pela sacralidade liberal do direito à propriedade, ou

\footnotetext{
${ }^{1}$ A crise democrática tem sido o tema de um amplo debate em todo mundo, tão grande que é quase impossível recensear todos os autores e autoras que descrevem esse momento. Mas se pensarmos no Brasil podemos, em linhas gerais, alcançar os traços dessa crise. Ainda que não tenhamos presenciado nenhuma interrupção terminal do regime e dos processos democráticos no Brasil após o fim da ditadura militar e do governo Sarney, é inegável que vivemos em um regime de crise, com alguns períodos de calmaria. Afinal, para resumir, em menos de 30 anos tivemos dois processos de impeachment, diversos escândalos de corrupção que atingiram todos os poderes da República e uma crescente insatisfação popular com a própria democracia, chegando ao ponto que elegemos em 2018 um presidente da República que, por inúmeras vezes, declarou seu desprezo pelo legislativo, seu apreço por governos totalitários, fazendo apologia a torturadores em detrimento e condenação dos Direitos Humanos. Todavia, a crise da democracia não está unicamente assentada no índice de satisfação popular, nos discursos antidemocráticos de lideres políticos, no combate aberto contra os Direitos Humanos, na negação das lutas identitárias, no recrudescimento dos nacionalismos (EUA, Brasil, Espanha, Hungria e outros) etc. Tudo isso são graves sintomas de um regime que foi incapaz de garantir uma vida digna e promover mudanças realmente profundas e estruturais na vida das pessoas diante do novo regime econômico sustentado pelo capital tecnológico. Especificamente no Brasil, conquistas como fim da inflação e a consolidação do Sistema Único de Saúde, somadas a uma série de avanços no campo dos direitos civis e nos programas de distribuição de renda amenizaram problemas como a fome, mas estão longe de propiciar para a grande massa de brasileiros uma vida autenticamente democrática. E o que seria isso? Para resumir: redistribuição não apenas de renda e de direitos, mas de bens e propriedades para atacar a pobreza estrutural, educação universal e de qualidade e, ainda, o respeito incondicional aos direitos civis e à vida de todos — dos pobres - por parte do aparelho policial do estado.
} 
pelo consenso elitista de que o governo depende do conhecimento objetivo de especialistas alinhados ao mercado. Neste texto, vamos explorar apenas o primeiro aspecto, investigar até que ponto as relações de sobredeterminação entre liberdade e democracia estruturam a democracia como um sistema permanentemente em crise.

\section{Democracia e liberdade}

O valor da democracia na tradição ocidental é um dogma quase inquestionável do campo da política. À democracia atribuímos a estruturação das condições de vida política mais elevadas e desejáveis: governo dos cidadãos (povo), regulação isonômica da esfera pública através do Estado e a salvaguarda jurídica e policial do direito individual mais fundamental: a liberdade. Além do mais, aceitamos a democracia como a melhor forma - ou regime — de governo porque, quando comparada a todas as outras, é a única que operaria com base no consentimento — voto livre — com a pretensão de atender de maneira justa uma comunhão de interesses. Desse modo, nos acostumamos a associar democracia e liberdade como dois lados de uma mesma moeda.

$\mathrm{Na}$ Grécia antiga, com o surgimento da democracia, ficou assegurado a todos os cidadãos a liberdade para discutir, participar e administrar (ou candidatar-se) os negócios públicos. Em seu livro A Política, Aristóteles descreve o governo democrático como aquele em que o povo, reunido em assembleia, administra todos os negócios públicos por meio de decretos e leis. A Assembleia estava estruturada a partir de dois direitos e de um dever. O primeiro direito, fundamental até os nossos dias, é a isonomia, isto é, a igualdade perante a lei entre todos os cidadãos. O segundo direito, também central até hoje, é a isegoria, a garantia legal para que todos os cidadãos possam se manifestar — ter voz — na Assembleia. Todavia, entre os gregos esses direitos vinham acompanhados de uma obrigação: a parrhesia ${ }^{2}$. Enraizado na

\footnotetext{
2 Uma excelente discussão sobre parrehsia e democracia pode ser encontrada no artigo de Cesar Candiotto, Parrhesia filosófica e ação política: Platão e a leitura de Foucault ( $p$. 35, 2011): “Contudo, tanto na democracia ateniense quanto na monarquia de Siracusa há uma ambiguidade valorativa da parrhesia. Na democracia, a parrhesia é vista positivamente porque nela todos podem tomar a palavra e expressar o que pensam; no entanto, em razão
} 
prática da comunidade nos séculos IV e V a.C., a parrbesia, manifestação da inseparabilidade entre dever e virtude, impunha ao cidadão a obrigação (dever) de dizer corajosamente (virtude) o que ele realmente (francamente) pensava sobre os assuntos públicos. A parrhesia, espécie de antídoto contra a demagogia e a apatia política, remontava à obrigatoriedade da sinceridade da fala e ao discurso como prática política. Evidentemente, em uma Assembleia, onde tudo pode ser discutido, algumas pessoas podem ser mais bem qualificadas do que outras para opinar sobre determinados temas. Sócrates, personagem no Protágoras de Platão, argumenta que quando a Assembleia ateniense está discutindo a edificação de casas e prédios, os cidadãos devem e podem considerar a fala dos construtores em detrimento do discurso dos leigos sobre o tema; assim, se alguém que o povo não considera um especialista no tema tenta aconselhá-los, não importa quão "bonito, rico e bem nascido ele seja, nenhuma dessas coisas os induz a aceitá-lo: não somente não lhe dão ouvidos, como riem dele, até que, atemorizado com a assuada, desista de falar" (PLATÃO, 2002, p. 61). No entanto, continua Sócrates, “quando a deliberação diz respeito à administração da cidade, qualquer indivíduo pode levantar-se para emitir opinião" (PLATÃO, 2002, p. 63), não importa, conclui o filósofo, seja um ferreiro, um sapateiro, um comerciante, um capitão do mar, um homem rico ou pobre, de boa família ou não. $\mathrm{Na}$ Assembleia, a isegoria (igualdade) e a liberdade são direitos de todos os cidadãos. A Assembleia na democracia grega representa a criação do espaço público por excelência, marca o nascimento da democracia direta, sem distinção entre pessoas e representantes, entre cidadãos e especialistas. A primeira expressão grega do regime democrático determinou, portanto, a criação da liberdade política - no caso dos gregos, do direito a todo cidadão a ter direitos na esfera pública.

do risco da demagogia, é difícil saber quem pode ter a excelência ética para o exercício do bom governo democrático. Inexiste democracia sem liberdade de palavra, mas essa liberdade de palavra pode, paradoxalmente, tornar a democracia inoperante. Esse paradoxo, levantado por Foucault por ocasião da análise da parrhesia política nos textos de Eurípides e Tucídides, resulta na quase impossibilidade do exercício da parrhesia na democracia ateniense. Cf. CANDIOTTO, Cesar. Parrhesia filosófica e ação política: Platão e a leitura de Foucault. Revista de Filosofia Aurora, Curitiba, v. 23, n. 32, p. 31-52, 2011. doi: http://dx.doi.org/10.7213/rfa.v23i32.1726.

em: https://periodicos.pucpr.br/index.php/aurora/article/view/1726/1633. Acesso em: 12 out. 2020. 
Pierre Grimal, historiador e latinista francês, em Os erros da liberdade, um livro provocativo, mas esquecido nos nossos dias, ao discutir a experiência da política entre os antigos, gregos e romanos, nos mostra como a construção do mito da liberdade como realização plena da vida é indissociável de violências, guerras, massacres e tiranias. À liberdade, diz Grimal, sempre opomos a morte. Assim, em janeiro de 48 ou 49 AC, momentos antes de atravessar o Rubicão, Júlio Cesar discursou para os seus soldados, afirmando que saía da legalidade para salvaguardar a liberdade cívica dos romanos. César, lembra Pierre Grimal, começou a guerra civil para garantir o direito legal dos tribunos de exercerem a censura contra todo o corpo político. Cinco anos mais tarde, Brutus assassinou César para devolver Roma à liberdade. "Havia não uma liberdade, mas duas: a que César reclamava e a que reclamavam os seus adversários” (GRIMAL, p. 20, 1990). Mas o que interessa nesse momento, para efeito de análise, é o sentido alargado que a liberdade adquiriu na antiga Roma, muito antes de Júlio César. Desde o tempo dos reis, em Roma escreviase liberdade como libertas com referência ao estatuto jurídico que reconhecia a condição de cidadão e, por extensão, todos os direitos relativos:

Ao longo da mais antiga tradição romana, nunca interrompida desde o tempo dos reis, a liberdade é independente da forma de constituição que rege a cidade; é o nome que se dá ao fato que nessa cidade acha-se garantido o estatuto jurídico de cada um: o fato de que se é cidadão [...]. Nela e assim reduzida ao essencial, essa realidade tangível, cotidiana, a segurança que não se pode ser atingido por uma pena corporal, nem aprisionado, nem constrangido, sem julgamento, a uma multa; que um julgamento, qualquer que seja, só pode ser pronunciado contra si por um tribunal regularmente constituído e composto por cidadãos detentores dos mesmos direitos do acusado. Ser livre, nessas condições, é, negativamente, não ser escravo (GRIMAL, p. 22, 1990).

A libertas, portanto, indo além da isonomia e da isegoria grega, era uma entidade de direito fundada em dois princípios, um negativo e outro positivo. No segundo caso, a libertas concedia a todo cidadão, chefe de família, o direito ao exercício da política. Do ponto de vista negativo, como o texto de Grimal revela, libertas é uma salvaguarda, uma garantia que protegia todos os cidadãos contra os possíveis excessos e abusos de outros cidadãos e autoridades. A libertas, na sua potência máxima, limitava o imperium, o poder supremo dos reis para dispor da vida dos cidadãos. A todo o 
cidadão, conforme uma tradição jurídica fundada na lenda de Horácio ${ }^{3}$, estava garantido o ius provocationis, o direito de apelação a um poder superior, o tribunal do povo que tinha a prerrogativa de deliberar conta o poder do imperium, contra a decisão do rei e dos tribunais. Assim, a libertas romana, sobretudo durante a República, mais do que propriamente consistir em um direito a fazer tudo, concede ao cidadão romano proteção legal, incluindo nesse caso a sua família, a sua propriedade e o seu corpo:

Essa independência diz respeito à sua existência e não aos seus atos, submetidos a todas as espécies de limitações, às leis, à hierarquia, aos costumes e, sobretudo, ao mos maiorum (a maneira de fazer dos antepassados) que dominará toda a história moral de Roma (GRIMAL, p. 31, 1990).

Portanto, a liberdade como salvaguarda individual, como limite ao poder do imperium, é um direito assentado no respeito e reconhecimento das leis e costumes e, sobretudo, na soberania da assembleia do povo contra a força e a vontade individual de quem poderia dispor da vida dos cidadãos, das autoridades que poderiam colocar os cidadãos em uma situação de dependência total. Todavia, o que podemos fazer quando reconhecemos que o espaço político é dominado pelo conflito, por oposição de forças que lutam pela liberdade e contra a própria liberdade? O que podemos fazer quando a ameaça à liberdade não vem do poder instituído, mas está dispersa, ramificada em diversos agentes políticos que lutam pelo poder? Nos Discursos

Sobre a Primeira Década de Tito Lívio, Maquiavel nos mostra que a libertas pode ser pensada como um direito que vai além da salvaguarda de direitos individuais, pois desde a República Romana ela tornou-se a expressão de uma condição difusa e ambígua: o direito de agir contra a liberdade e, ao mesmo tempo, o direito à resistência à dominação dos grandes. No capítulo IX de O Príncipe, Maquiavel também reafirma essa ideia seminal da liberdade como direito à luta contra a dominação. $\mathrm{O}$

\footnotetext{
${ }^{3}$ Horácio, ao regressar a Roma vencedor de uma batalha, matou a própria irmã que chorava a morte de um de seus inimigos. Não sendo julgado pelo tribunal da família pelo assassinato da irmã, coube ao rei sentenciar Horácio à morte por decapitação. Diante da pena capital imposta pelo rei, Horácio apela aos seus concidadãos (assembleia do povo) que, por sua vez, o inocentam, criando assim uma situação jurídica nova: a maiestas - poder jurídico supremo - deixava de pertencer ao rei e aos tribunais e passava para o povo.
} 
conflito entre os grandes e os pequenos, entre o povo e a nobreza, está na origem dos Estados e, por consequência, da própria política, estabelece Maquiavel. Resumidamente, os estados opõem duas forças: os grandes aos pequenos. Os primeiros são poucos, fortes e desejam dominar e oprimir. Já os pequenos são muitos e querem, num primeiro momento, escapar ao jugo dos fortes:

[...] digo que se alcança o principado ou pelo favor do povo ou pelo favor dos poderosos. Em todas as cidades acham-se essas duas tendências diferentes e isso vem do fato que o povo não quer ser dominado e nem oprimido pelos poderosos, e estes desejam governar e oprimir o povo. Desses dois apetites distintos origina-se, nas cidades, um dos seguintes resultados: principado, liberdade, desordem (MAQUIAVEL, p. 73, 1999).

Portanto, conforme está no Príncipe, todo conflito político (luta pelo poder) é uma luta livre e, ao mesmo tempo, contra e a favor da liberdade. Entretanto faz-se necessário considerar que se o conflito está na origem do poder isso significa, também, que ele está sempre em causa, em disputa, pois a sua posse será momentânea e dependente do jogo de forças que opõe os grandes aos pequenos. Essas duas concepções de Maquiavel, o poder como um lugar de disputa e a liberdade (ou a vida livre) como finalidade e motivo das lutas políticas pelo poder, são ideias seminais para a concepção lefortiana do poder democrático como um lugar vazio e para a noção de democracia radical, conforme podemos ler na obra de Chantal Mouffe.

Ciente desse problema diagnosticado por Maquiavel, a tradição contratualista repensou a origem do poder civil. A lógica da força ganhou a companhia do direito, e às disputas e lutas pelo poder foram contrapostos os mecanismos jurídicos do pacto social. Para Hobbes, assim como para Rousseau, por exemplo, a descoberta de direitos universais e pré-políticos tornou possível a ideia do pacto social: uma associação política para defender e garantir o direito à vida, no caso de Hobbes ou, tratando-se de Rousseau, destinada a preservar a liberdade.

$\mathrm{Na}$ perspectiva do Contrato Social de Rousseau, publicado quase 30 anos antes da Revolução Francesa, a ordem civil e o poder soberano só podem ser legitimamente instituídos por meio de um pacto social. A premissa geral rousseauniana - aparentemente próxima da noção de democracia deliberativa sustenta que os homens são naturalmente livres e independentes e que não há 
autoridade natural de homem nenhum sobre seus semelhantes. Rousseau, no Contrato Social (livro 1, Capítulos: II, III, IV), rejeita qualquer convenção que queira fundar uma ordem civil baseada: i) na mais antiga das sociedades, a família (nela os homens se ligam apenas por uma necessidade de sobrevivência, que logo passa, e quando isso acontece eles se tornam senhores de si, livres e independentes.); ii) no raciocínio aristotélico que sustenta que os homens não são naturalmente iguais, que uns nascem destinados a dominar e outros a serem dominados; iii) no pretenso direito do mais forte (da força não resulta direito algum e a ela só se obedece por prudência e nunca por dever; cessando a obrigação, a força, não há mais dever, não há mais direito e este não se constitui coisa volúvel assim, que se dissipa com tanta facilidade); iv) na alienação voluntária da liberdade em favor de um déspota; v) no direito de escravizar decorrente da guerra. Contra todas essas perspectivas tácitas — naturais ou históricas — de submissão, a obra de Rousseau estabeleceu a lógica do pacto. O poder político só é legítimo se for contratado, pactuado, acordado por homens livres e iguais. Desse modo, logo na abertura do Contrato Social, Rousseau manifesta o objetivo primordial da sua obra: "Quero indagar se pode existir na ordem civil alguma regra de administração legítima e segura, tomando os homens como são e as leis como devem ser. Esforçar-me-ei sempre, nessa procura, para unir o que o direito permite ao que o interesse prescreve afim de que não quem separadas a justiça e a utilidade (ROUSSEAU, 1978 p. 21). Todavia, como fazer um contrato sem se despojar da liberdade? Paradoxalmente, no capítulo VI do livro I do Contrato Social, Rousseau nomeia como cláusula fundante do pacto social a alienação total e irrestrita de cada contratante. A partir da alienação voluntária não restará direito ou vontade particular alguma, pois seriam a causa da ruína do pacto: "Essas cláusulas, quando bem compreendidas, reduzem-se todas a uma só: a alienação total de cada associado, com todos os seus direitos à comunidade toda" (ROUSSEAU, 1978, p. 32). No ato de alienação o indivíduo une a sua vontade particular a uma única vontade, leva a sua própria vontade ao grau máximo de realização, agora transformada em um único tecido, a vontade geral. A alienação sem reservas impõe que cada contratante esteja submetido a todos (e esse "todos" se expressa pela vontade geral) e, ao mesmo tempo, seja parte integrante dela. Por isso mesmo, na economia ambígua do texto de Rousseau, após a alienação, cada contratante obedece apenas à sua própria vontade: 
Enfim, cada um dando-se a todos, não se da' a ninguém e, não existindo um associado sobre o qual não se adquira o mesmo direito que se the cede sobre si mesmo, ganha-se o equivalente de tudo o que se perde, e maior força para conservar o que se tem (ROUSSEAU, 1978, p. 33).

A alienação universal, cláusula fundamental do pacto social, cria as condições políticas para a liberdade e a igualdade. No âmbito do Contrato Social, a liberdade consiste no direito do cidadão em dar leis a si mesmo numa cadeia de relações e compromissos com a comunidade política. Portanto, a liberdade, o direito de seguir a própria vontade, de um direito natural limitado às forças individuais, ganha, com o contrato social, o amparo das leis e a proteção do Estado:

Poder-se-ia, a propósito do que ficou acima, acrescentar à aquisição do estado civil a liberdade moral, única a tornar o homem verdadeiramente senhor de si mesmo, porque o impulso do puro apetite é escravidão, e a obediência à lei que se estatui a si mesmo é liberdade" (ROUSSEAU, 1978, p. 37).

Portanto, a vontade geral ${ }^{4}$, poder soberano e legítimo nascido do pacto social, é a expressão política do ser da vontade, dirigida para assegurar um interesse comum de todos os homens, isto é: uma existência livre e igual. O pacto social na perspectiva de Rousseau não está, é verdade, estruturado em uma comunhão de diferenças, mas em um interesse comum a todas as vontades: a liberdade. A cláusula original do pacto resulta de uma unidade primordial e universal: a vontade de ser livre.

$4 \mathrm{O}$ ato de alienação da origem de imediato à vontade geral, ao mesmo tempo em que coloca todos os cidadãos em situação de igualdade, pois todos estão submetidos à vontade geral, sem exceções. Todavia, obedecer à vontade geral é, conforme o texto de Rousseau, obedecer a si mesmo, pois a vontade geral é esse ente político, esse tecido que expressa uma vontade que habita, sem distinções, todos os seres humanos: a vontade de ser livre. Portanto, ela é geral não porque submete a todos, mas porque é encontrada, indistintamente, em todos os seres humanos. "Há muitas vezes grande diferença entre a vontade de todos e a vontade geral: esta olha somente o interesse comum, a outra o interesse privado, e outra coisa não é senão a soma de vontades particulares; mas tirai dessas mesmas vontades as que em menor ou maior grau reciprocamente se destroem, e resta como soma das diferenças a vontade geral" (ROUSSEAU, 1978, p. 56). 
A fórmula da liberdade civil — obedecer a vontade geral é obedecer a si mesmo - nascida da alienação voluntária dá origem a novos entes políticos, como Rousseau explica no capítulo IV do Livro II do Contrato Social:

[...] a república ou o corpo político, [...] Estado quando passivo, soberano quando ativo [...]. Quanto aos associados, recebem eles, coletivamente, o nome de povo e se chamam, em particular cidadãos, enquanto partícipes da autoridade soberana, e súditos enquanto submetidos às leis do Estado" (ROUSSEAU, 1978, p. 73).

Enquanto a lei deve nascer da vontade, o governo, como está no livro III, é o agente político intermediário entre o Estado e os cidadãos, um dispositivo político desprovido de vontade própria e, por consequência, não livre: “É um corpo intermediário estabelecido entre os súditos e o soberano para a sua mútua correspondência, encarregado da execução das leis e da manutenção da liberdade, tanto civil como política” (ROUSSEAU, 1978, p. 74). O governo, nesse sentido, é uma máquina sem livre-arbítrio. Desse modo, no livro III do Contrato Social, o discurso rousseauniano muda de plano, passa do direito para a ciência política, passa dos fundamentos do pacto para a teoria de governo. Como, então, deve ser o governo? Os dois primeiros pontos rousseaunianos sobre o governo são de natureza negativa, pois dizem o que o governo não é e, principalmente, estabelecem o que ele não deve fazer. São postulados universais, ou seja, servem para todos os Estados e para todas as formas de governo. Portanto, não cabe ao governo fazer leis, pois ele não é um corpo legislativo, trata-se tão somente de um corpo executivo desprovido de vontade própria. O governo, em si mesmo, não é uma fonte de poder. Ele atua com poder e autoridade delegada, permanece sempre subordinado à vontade geral. Todavia, o governo, ao mesmo tempo que é necessário, também representa uma ameaça constante ao poder soberano. Todo governo tem uma tendência - quase que um ímpeto natural antidemocrático — de se apropriar do Estado, de confundir-se com o poder soberano e colocar-se acima das leis e esquecer-se da sua função de encarregado: “[...] quando o príncipe não mais administra o Estado de acordo com as leis e usurpa o poder soberano. [...] quando os membros dos governos usurpam isoladamente o poder [...]" (ROUSSEAU, 1978, p. 111).

Como evitar a usurpação do poder por parte do Governo? Como impedir que o governo deixe de ser um agente do Estado para ocupar o lugar do poder soberano? 
Nesse ponto, Rousseau reintroduz, ao mesmo tempo, o expediente grego da democracia direta e a concepção romana de libertas. A reunião constante e frequente do povo, na forma de assembleias estabelecidas previamente pela lei, é o dispositivo de poder legítimo que pode limitar o governo à sua condição de poder intermediário. Há um compromisso prévio, um dever cívico, fixado pela lei, anterior e independente do governo, que impõe a cada cidadão o dever de participar das assembleias "legítimas". Para Rousseau, não basta que o povo promulgue as leis e escolha um governo, pois a sobrevivência do pacto, a inviolabilidade da vontade geral, dependem da presença do povo no espaço público. A única forma de evitar a usurpação do poder pelo governo ou por todas as formas de vontade particular - partidos políticos, igrejas, classes sociais etc. - é a voz ativa da vontade geral, o exercício político da liberdade através da ocupação dos espaços públicos de poder pelo poder soberano, a visibilidade e a presença do poder soberano na sua forma original, o povo. Portanto, o povo, após o pacto, só se reconhece como tal nas assembleias. O cidadão, o particular, o trabalhador isolado não é, em si mesmo, o povo, não representa a forma essencial do povo. O povo somente torna-se povo nas assembleias, na ocupação das cidades, no exercício de deliberar, impondo diretamente ao governo a sua vontade. A vigilância constante e permanente do povo é o remédio contra a usurpação do poder pelo governo, ou seja, pelo encarregado:

Não basta que o povo reunido tenha uma vez fixado a constituição do Estado sancionando um corpo de leis; não basta, ainda, que tenha estabelecido um governo perpétuo ou que, de uma vez por todas, tenha promovido a eleição dos magistrados; além das assembleias extraordinárias em que os casos imprevistos podem exigir, é preciso que haja outras, fixas e periódicas, que nada possa abolir ou adiar, de tal modo que, no dia previsto, o povo se encontre legitimamente convocado pela lei, sem que haja necessidade de qualquer outra convocação formal (ROUSSEAU, 1978, p. 104).

Como o texto acima estabelece, o direito às assembleias do povo não depende do governo; nasce do próprio do pacto e, nesse sentido, é irrevogável por qualquer governo. Assim, na república rousseauniana, a democracia direta não representa uma forma de governo, mas o modelo de um regime constitucionalista, a forma de poder soberano que antecede e funda o Estado, faz as leis e estabelece o governo. O

Contrato Social, portanto, reinaugurou na modernidade a noção de espaço público 
como o lugar da liberdade política, refundando a noção grega de Assembleia, concedendo a ela algo mais do que a maiestas romana, o poder jurídico-político supremo. Desse modo, a grande novidade do Contrato Social é o restabelecimento dos fundamentos de uma democracia direta no pensamento político moderno. Primeiro, o contrato está na origem do Estado e é, nas palavras de Rousseau, uma “obra de arte” (ROUSSEAU, 1978, p. 102). O pensamento rousseauniano sustenta, ainda que de maneira não inédita, um princípio fundamental do republicanismo moderno presente em todas as constituições democráticas: a separação entre Estado e governo. Para compreender a liberdade gestada no domínio do Contrato Social, deve-se respeitar a ordem das razões. Do pacto, imediatamente, nasce o poder soberano, os súditos, os cidadãos, o Estado, os cidadãos e, num segundo momento, promulgam-se as leis e só então, num tempo bem posterior, institui-se o governo e, o mais importante, na condição de encarregado.

Se a concepção rousseauniana do Contrato Social pode ser considerada a afirmação das condições teóricas de possibilidade de uma nova concepção de liberdade política, no século XIX, após os ecos das Revoluções Americana e Francesa, o tema da liberdade — assim como o das lutas pela democracia — passou a ser pensado não somente a partir dos seus fundamentos filosóficos, mas também em referência à sua situação histórica.

Em 1819, com o objetivo de discutir a relação entre os excessos da Revolução Francesa e a obra de Rousseau, mais precisamente a concepção rousseauniana de liberdade, Benjamin Constant estabeleceu a significação nodal acerca da relação de sobredeterminação entre liberdade e democracia. Para Constant, sem perceber, os revolucionários jacobinos perpetraram muitos excessos porque buscaram inspiração em Rousseau que, por sua vez, errou ao cometer um verdadeiro anacronismo, transportando para o mundo moderno os princípios dos antigos. Portanto, o grave equívoco de Rousseau forneceu desastrosos pretextos a mais de um tipo de tirania como, e por exemplo, aquela dos crimes jacobinos. Segundo Constant, da Grécia à Republica romana, encontramos apenas "traços do governo representativo" e, por consequência, da liberdade que decorre desse tipo de governo. Já os antigos, em que leis regulavam os costumes, as vontades individuais eram controladas pelo estado. E a liberdade, por outro lado, tinha lugar na praça pública, na ágora, no espaço legado 
aos homens para decidirem diretamente o destino dos seus estados. A liberdade consistia em soberania política. Já para os modernos, conforme Constant, a liberdade, de modo geral, vivida na vida privada, é a salvaguarda dos direitos individuais básicos: credo, opinião, propriedade etc. Para os antigos a liberdade era vivida na partilha do poder social entre todos os cidadãos, enquanto para os modernos, a liberdade é a salvaguarda dos privilégios privados garantidos pelas instituições. Entretanto, mais importante do que a distinção entre as formas de liberdade, é preciso prestar atenção à lógica que articula as relações de sobredeterminacão entre democracia e liberdade e que parece mover toda análise de Constant: as condições sociais, o estilo de vida, as relações econômicas (por exemplo o comércio, como está no exame de Constant), os novos costumes articulam um tipo de existência, uma experiência própria da liberdade que, por sua vez, parece moldar ou exigir uma certa forma do regime político. Por isso Constant pode concluir que o grande erro de Rousseau foi não considerar que a liberdade individual, experimentada na dimensão da vida privada, é a primeira necessidade dos homens modernos, necessidade essa que não deve ser sacrificada à liberdade política; ao contrário, deve ser preservada pelos governos e instituições.

Portanto, a construção das democracias, ou das diferentes concepções de esfera política, determinaram as diferentes formas e experiências de liberdade. Começamos com práxis política na ágora (gregos) pela instituição da liberdade política, do direito a ter voz e a participar. Entre os romanos, ainda no tempo dos reis, anterior à República, a liberdade foi pensada como libertas, como proteção à pessoa contra o poder do absoluto do imperium. Com Maquiavel, a liberdade foi, sobretudo, pensada como direito a resistir e a lutar em função de um contexto permanente de conflito. Em Rousseau, com o pacto social e a instituição da vontade geral, a liberdade civil reconfigurou-se para o direito de autogovernar-se, de dar leis a si mesmo. Finalmente, chegamos com Constant na liberdade liberal, quando ela se verticalizou em direção ao individualismo e à vida privada, atendendo aos anseios da nova sociedade burguesa, isto é, se tornou o espírito de época do homem moderno para, de certa forma, com o passar do anos a se consolidar, ambiguamente, como meio (o livre 
direito à luta) e como fim de todas as nossas lutas políticas mais importantes, sejam elas democráticas e antidemocráticas, emancipatórias ou contraidentitárias ${ }^{5}$.

\section{A crise}

Assim, desde o século XIX, experimentamos essa ambiguidade de viver entre o determinado e o indeterminado, pois sabemos que se toda luta por democracia é uma luta por liberdade, nem toda luta por liberdade é democrática, como podemos ler na peça acusatória de Constant contra Rousseau. No século XX, em uma passagem muito conhecida de A Lógica Totalitária, ao discutir a dificuldade da esquerda em elaborar uma teoria do estado e da política dado que, entre outras coisas, não entendeu o capitalismo como um produto do Estado moderno nascido das revoluções liberais, Lefort sustenta que a originalidade da democracia, aquilo que a diferencia sobremaneira dos regimes totalitários e despóticos, está em estruturar e oferecer as condições políticas de poder destinado a permanecer vazio, sem dono e sem

\footnotetext{
${ }^{5}$ Para rediscutir o tema da liberdade, um bom caminho, se não podemos ler Locke, Rousseau, Kant, Hegel e Stuart Mill diretamente, está na obra de Isaiah Berlin de 1959. No excelente ensaio Dois conceitos de liberdade, seguindo a lógica de Constant, Berlin apresentou a liberdade a partir de duas matrizes, uma liberal e outra republicana, estabelecendo que a liberdade pode ser negativa ou positiva. Resumidamente as diferenças entre as duas noções são: a liberdade negativa (liberal) corresponderia aquela noção de "estar livre de" qualquer interferência externa; enquanto a liberdade positiva (republicana) corresponderia a "estar livre para" agir conforme a sua vontade. Berlin descreve o sentido político da liberdade negativa da seguinte forma: A liberdade política ... é simplesmente a área na qual um homem pode agir sem ser obstruído por outros. Só não temos liberdade política quando outros indivíduos nos impedem de alcançar uma meta.

Já a liberdade positiva caracteriza-se pela presença da ação, da participação na tomada de decisões, da autodeterminação; o sentido 'positivo' da palavra 'liberdade', provém do desejo que o indivíduo nutre de ser o seu próprio senhor (BERLIN, 1969). Estamos no domínio das ideias de autonomia e do autogoverno, que se realizariam politicamente através de um estado constitucionalista, como, de modo geral, estabeleceu Montesquieu na obra O Espírito das Leis: "A liberdade consiste em fazer tudo o que as leis permitem". Portanto, de um lado, somos livres quando não temos impedimentos e, de outro, quando a lei expressa a nossa vontade. Todavia, essas duas concepções, alguém poderia argumentar, não nos protegem de abusos, violações e das nefastas formas de desigualdade: política, econômica, social, gênero etc. Desse modo, alguém guiado pela crença irrestrita na liberdade negativa estaria autorizado a empregar todos os meios para atingir seus fins. Como também, um outro sujeito coletivo ou não, comprometido com a leitura estrita do sentido volitivo inerente à liberdade positiva, poderia argumentar e lutar incessantemente para que a lei expressasse as suas vontade e interesses, mesmo a despeito de outros agentes políticos.
} 
identificação, não podendo ser definitivamente ocupado ou legitimamente tomado por nenhum homem, família, grupo social particular, ideologia, tradição ou mesmo por representantes de um determinado credo.

A legitimidade do poder funda-se sobre o povo; mas a imagem da soberania popular se junta a de um lugar vazio, impossível de ser ocupado, de tal modo que os que exercem a autoridade pública não poderiam pretender apropria-se dela. A democracia alia esses dois princípios aparentemente contraditórios: um que o pode emana do povo; outro, que esse poder não é de ninguém. Ora, ela vive dessa contradição (LEFORT, p. 76, 1983)

Nenhuma forma, nenhum corpo, nenhum objeto tem o direito ou, mesmo a potência, para encarnar o poder, dando-lhe uma imagem na qual a sociedade reconheceria a sua própria identidade e unidade, pois esse tipo de identificação, diz Lefort, é característico do totalitarismo. Ao conceber o poder nascido da éris constitutiva do político conforme a tradição de Maquiavel e, ao mesmo tempo, fundado no princípio rousseauniano da soberania popular, Lefort fornece novos contornos à relação de sobredeterminação entre liberdade e democracia. A disputa pelo vazio permanente esclarece, de certo modo, a tensão constitutiva e insuperável entre liberdade e democracia. Não há, sem dúvida alguma, democracia sem liberdade, mas toda luta por liberdade é uma luta por poder. Como, também, nem todo discurso a favor da liberdade é democrático. Portanto, toda forma de liberdade individual — não conformada ao sistema, sem restrições e sem compromissos — representa uma ameaça à democracia. Por outro lado, a democracia, como já alertava Constant, também pode ser uma ameaça ou até mesmo uma negação da liberdade. Nesse sentido, o dilema de como conjugar liberdade e democracia, nascido e gestado pelas diferentes modalidades de liberdade, aprofundado pela liberdade dos modernos, pode nos ajudar a entender, pelo menos em parte, o sentido da democracia contemporânea como um regime permanentemente em crise, instado pela ambígua intensidade da vida democrática: o direito à liberdade individual e a convicção de que devemos limitar a zona de ação dos indivíduos ao limite da inviolabilidade do espaço vazio de poder.

Para ilustrar os diferentes matizes que compõem o dilema ou a relação sobredeterminação entre democracia e liberdade, vamos retomar, rapidamente, os 
apontamentos de Agamben ${ }^{6}$ a respeito do modo como os governos, sobretudo da Itália, têm lidado com a crise do COVID-19. Não somente Agamben 7 , mas diferentes grupos políticos radicais e partidos de ultradireita têm apontado para o perigo de uma mudança profunda no nosso modo de ser e viver, ocasionada pela gestão da crise do COVID-19. Eles não estão se referindo apenas aos impactos sanitários, econômicos e sociais mas, sobretudo, ao risco de submissão da vida privada, dos direitos individuais às políticas destinadas a conter a grave crise de saúde pública. Resumidamente, para salvar vidas, estaríamos cometendo os erros de Rousseau, subordinando a liberdade individual à política. Estaríamos vivendo uma transformação nas relações de sobredeterminação entre liberdade e governo, com franco avanço dos governos sobre a liberdade. Com a crise do COVID-19 estaríamos restaurando o poder do imperium. Agamben, em um artigo, L'invenzione di un'epidemia, publicado em 26 de fevereiro no blog Quodlibet, denunciava, em tom negacionista, o avanço contra a liberdade presente nas estratégias sanitárias dos governos europeus, sobretudo o Italiano. Para autor de Homo Sacer, um dos mais celebrados filósofos da atualidade, esgotado o medo da ameaça do terrorismo que justificasse políticas de exceção, a crise do COVID -19, alimentada pelo medo da morte febril, solitária e sem ar que parece nos assombrar a cada espirro, apareceu como o motivo do momento - "o pretexto ideal" - para que os governos adotassem medidas excepcionais contra a liberdade em nome da saúde e da segurança. Em 17 de março de 2020, quando a situação de pandemia já estava estabelecida na Itália e em boa parte do mundo, em um novo texto, Chiarimenti, Agamben reforça o fato de que os italianos estariam dispostos a sacrificar a liberdade e um modo de vida autenticamente político em nome da sobrevivência. Para autor, o pânico da morte viral, o nosso apego à vida nua não é algo que une os homens, mas os cega e os separa. Aceitamos, conforme o autor, o estado de exceção como se fosse normal. Cegos pelo medo e imobilizados pelos discursos e políticas de biossegurança, esvaziamos os espaços públicos, nos contentamos somente com encontros à distância, concordamos passivamente em enterrar os nossos mortos sem velá-los e,

\footnotetext{
${ }^{6}$ Disponível em: https://www.quodlibet.it/giorgio-agamben-chiarimenti. Acesso em: 15 jun. 2020.
} 
assim, permanecemos presos em nossas casas acreditando que o fim da liberdade será apenas provisório e emergencial. Desse modo, alerta Agamben, devemos nos preocupar não apenas com o nosso presente, mas com a interdição definitiva da nossa liberdade fundada em medidas de proteção sanitária. Assim, aparentemente, o argumento da ameaça à liberdade, como estabeleceu Agamben, invariavelmente está conectado ao regime fundador da sociedade e da democracia moderna: a invasão e o sequestro da liberdade individual.

Muito antes do texto de Agamben, Rancière expressava, ainda nos primeiros anos do novo milênio, a sublevação elitista e oligárquica contra a democracia em função das lutas por liberdade. Diferentemente de Agamben, Rancière nos alerta para o sequestro da liberdade política. Em $\mathbf{O}$ ódio à democracia, Rancière nos mostra como a liberdade — o seu uso universalizado — tem colocado uma série de dilemas à democracia representativa. Em suma, o sentimento dos que odeiam a democracia pode ser sintetizado na seguinte sentença: "só existe uma democracia boa, a que reprime a catástrofe da civilização democrática" (RANCIÈRE, p. 11, 2014a). Se motivos e indícios ambientais para o fim da civilização não faltam, é importante saber que a boa democracia, aquela que poderia nos livrar, no contexto determinado da política, de uma catástrofe civilizatória, está assentada na gestão da liberdade, tanto individual quanto política. É preciso ter claro que o ódio à democracia é difuso e pode ser explicado por sentimentos compartilhados pela elite econômica mundial, por seitas e crenças religiosas, por partidos e grupos políticos sectários e contrários a uma experiência massiva e universal da liberdade.

Está claro, desde a crítica de Constant a Rousseau, que a boa democracia, assentada no elogio à liberdade individual e no sistema político representativo parlamentar, estava a serviço das elites que se opunham ao governo da vontade geral e pretendiam governar em nome do povo, mas sem a participação direta deste. A representação, diz Rancière, "nunca foi um sistema inventado para amenizar o impacto do crescimento das populações” (p. 69, 2014a), mas sim para assegurar aos privilegiados os mais altos graus de representatividade. Rancière é enfático ao afirmar que os pais das revoluções francesa e norte-americana sabiam exatamente o que estavam fazendo. O sistema representativo nasceu para sustentar a exclusão, a desigualdade e reservar o exercício da liberdade política para poucos. É preciso ter em 
conta que democracia moderna não nasceu como direito a todos: nasceu em sociedades escravocratas, em impérios coloniais e com a participação limitada às elites. O discurso de Constant é um elogio e uma defesa do estilo de vida e dos privilégios do homem burguês, de uma sociedade, pelo menos levando em conta o século XIX e boa parte do XX, no qual a liberdade é um direito limitado a um certo tipo homem. Esse sistema assentado em um governo como gestor da liberdade para poucos, somente foi possível pela estruturação da esfera pública a partir de mecanismos de exclusão política e de privação da cidadania e, por extensão, da interdição de uma experiência universal da liberdade. É o caso, como lembra Rancière, da mulher historicamente confinada à vida privada, sem direito a votar e a ocupar cargos públicos, sem direito à vida social, sem direitos políticos, isto é, sem liberdade política e individual. A situação de exclusão da mulher evidencia, pelo menos inicialmente, o paradigma da liberdade democrática moderna: a liberdade é um direito soberano e inviolável, mas para poucos. Assim, seguindo a crítica de Rancière, o ódio à democracia e a sua a crise resultam, em parte, da ameaça a esse sistema oligárquico — travestido de democracia — fundado na invenção política moderna, descritas por Constant e Lefort: a liberdade individual para poucos. Entretanto, o século XX confronta a democracia com a experiência íntima e vascularizada da liberdade individual, sobretudo quando, por exemplo, consideramos as lutas identitárias e emancipatórias, as lutas por direitos civis em diferentes lugares do mundo, os eventos em torno do maio 68 e a reação de estudantes e trabalhadores contra as ditaduras militares, como ocorreu na América Latina. A gestão oligárquica da democracia, em resumo, foi confrontada com experiências e demandas por uma liberdade difusa e, ao mesmo tempo, concreta. Difusa, porque são muitas liberdades, são muitos atores; concreta porque nasce da vida. O ódio à democracia, muito evidente nos manifestos e discursos de partidos e dirigentes de extrema direita, é uma reação à liberdade, contra as lutas emancipatórias, contra a inclusão, contra a igualdade material e de direitos, contra a liberdade individual radicalizada para todos e todas, reivindicada pelos pobres, pelos negros e negras, pelas mulheres, homossexuais etc. O ódio está na democratização jurídica e material da liberdade. 
Não vivemos em democracias. Tampouco vivemos em campos, como garantem certos autores que nos veem submetidos às leis de exceção do governo biopolítico. Vivemos em estados de direitos oligárquicos, isto é, em Estados em que o poder da oligarquia é limitado pelo duplo reconhecimento da soberania popular e das liberdades individuas (RANCIÈRE, p. 94, 2014a).

Desse modo, a reação à democracia por parte das elites está assentada em um operador ideológico que coloca em questão demandas autenticamente democráticas, como as mais diversas lutas emancipatórias e identitárias. A luta por igualdade - de gênero, raça, bem como as suas ações e políticas afirmativas institucionalizadas tem sido frequentemente reduzida ao espectro de um populismo ${ }^{8}$ alienante e ao desejo das pessoas de fazerem parte do mercado e da cultura de massa. Já os gritos por liberdade, nessa mesma retórica reificante das lutas, são frequentemente equiparados aos impulsos que conduziram ao totalitarismo. Desse modo, estabelece Rancière, pode-se atribuir aos "fenômenos de agravamento da desigualdade o triunfo funesto e irreversível da 'igualdade de condições’ e oferecer a empreitada oligárquica seu ponto de honra ideológico: é necessário lutar contra a democracia, porque a democracia é o totalitarismo" (RANCIÈRE, 117, p. 2014a). A radicalização da experiência democrática, as diferentes lutas por liberdade, tornaram-se, como a própria luta por igualdade, uma ameaça “à boa democracia”. Assim, o ódio à democracia, como também o fortalecimento de partidos nacionalistas e a formação e eleição de governos de extrema direita nos últimos anos, como podemos observar nos EUA, no Brasil e Hungria, são reações à luta democrática por uma experiência realmente universal e autêntica de liberdade e igualdade que coloca em questão o consenso dos modernos, as bases materiais do liberalismo econômico e os fundamentos do governo representativo, como gestor de uma cidadania para poucos. No âmbito das

\footnotetext{
8 "A própria ideia de democracia vê-se assim duplamente posta em causa. De um lado, a crítica do «populismo» denuncia um povo incapaz de compreender e de ir ao encontro da lei necessária do progresso histórico; do outro, a democracia é reduzida ao poder dos indivíduos consumidores e apresentada como um perigo mortal que ameaça a comunidade política e a ordem humana em geral." ( RANCIÈRE (2014b).
} 
democracias, a extrema direita avança opondo a noção muito própria de liberdade individual ${ }^{9}$ às lutas e conquistas democráticas por liberdade e igualdade.

Em 2011, em um texto intitulado Ainda se pode falar de democracia? Rancière opõe o desfalecimento da democracia representativa à reação do consenso oligárquico diante das demandas por liberdade, por melhores condições de vida, pela preservação dos sistemas públicos de saúde, de educação e de assistência social. A democracia tornou-se, portanto, essa condição de ameaça ao consenso político, àquela vida livre reservada somente ao tipo de homens que ouviam atentamente Benjamim Constant no início do século XIX. Todavia, enquanto um regime de excessos e concessões, enquanto um regime no qual o poder não é legitimamente de ninguém, a democracia, cedo ou tarde, confronta a liberdade e a igualdade com os limites impostos pelo consenso do mercado e das oligarquias.

\section{Conclusão}

Mais fundamental que a diferença entre as formas de liberdade, dos antigos e dos modernos, é a lógica de sobredeterminação articulando essas diferenças que parece explicar a democracia como um regime permanente de crise. Como uma

\footnotetext{
${ }^{9}$ A título de exemplo, o presidente do Brasil Jair Bolsonaro tem se colocado, em diferentes momentos, como um defensor radical da liberdade individual, uma concepção de liberdade, bem da verdade, que causaria temor até mesmo em Benjamin Constant. Para resumir, uma defesa da liberdade amparada: em propostas radicais de desregulamentação econômica (abertura total ao livre mercado), de flexibilização e extinção de leis e normas ambientais até a supressão de direitos e garantias civis e trabalhistas. No livre mercado; no direito a uma retórica sem medidas de contenção, contra o politicamente correto; na demanda pela posse de armas; no avanço da agricultura e da pecuária contra as reservas naturais; na autonomia dos pais em poder escolher transportar as crianças sem a interdição de regras de segurança de trânsito etc. No discurso de posse, realizado no primeiro dia de 2019, do começo ao fim, o presidente se apresenta como um defensor da liberdade: “Daqui em diante, nos pautaremos pela vontade soberana daqueles brasileiros que querem boas escolas, capazes de preparar seus filhos para o mercado de trabalho e não para a militância política |13| [Referência ao Escola Sem Partido]; que sonham com a liberdade de ir e vir, sem serem vitimados pelo crime; que desejam conquistar, pelo mérito, bons empregos e sustentar com dignidade suas famílias; que exigem saúde, educação, infraestrutura e saneamento básico, em respeito aos direitos e garantias fundamentais da nossa Constituição". Cf. https://www1.folha.uol.com.br/poder/2019/01/leia-a-integra-do-discurso-de-bolsonaro-nacerimonia-de-posse-no-congresso.shtml
} 
espécie de figura sobre um fundo, semelhante àquelas imagens ambíguas, democracia e liberdade se articulam de tal maneira que é impossível encontrar uma descartando a outra. Aliás, o grau de visibilidade da liberdade (a figura) depende, sobremaneira, da solidez do fundo, da democracia. Assim, entre liberdade e democracia se impõe uma lógica de sobredeterminação ambígua e intercambiável. Resumidamente, são duas situações possíveis que sustentamos ao longo desse texto: i) o sistema político, ao mesmo tempo em que se conforma também determina as diferentes formas e usos da liberdade, como parece ser a liberdade dos modernos e, por extensão, do liberalismo político; ii) as diferentes experiências e concepções de liberdade articulam ou sustentam as distintas lutas políticas e, por extensão, reconfiguram as nossas formas e sistemas democráticos.

Finalmente, gostaria de acrescentar um terceiro elemento a essa estrutura ambígua: a comunidade. É preciso ter em conta que as diferentes concepções clássicas de liberdade, respeitadas as suas diferenças, devem ser pensadas a partir de uma condição comum que as tornem politicamente possíveis, a união de dois entes complementares e interdependentes: vida e os interesses do indivíduo e da comunidade. A liberdade só funciona politicamente quando articulamos (submetemos) os nossos direitos individuais — de agir sem obstáculos ou de se conduzir conforme a nossa vontade - a um conjunto de princípios legais obediência às leis — e aos valores e práticas de alteridade - amor, amizade, solidariedade, equidade — reconhecidas no nosso mundo comum, na nossa comunidade. Além do mais, só podemos nos proteger da interferência externa, como supõe a liberdade dos modernos, ou, ainda, pensar em ser senhor das nossas próprias escolhas e ações, como expressa a noção de liberdade rousseauniana, a partir de um profundo senso de comunidade estruturado em torno da proteção da vida, da garantia e do reconhecimento, por parte dos membros da comunidade, dos nossos direitos à individualidade e a perseguir os nossos fins. Cabe à comunidade, através dos seus códigos de valores e aparatos políticos, nos proteger da indevida interferência do outro e, ainda, criar as condições ético-políticas para que as leis e os poderes instituídos expressem a vontade comum de todos os indivíduos. Recorrendo a uma expressão cara a Montesquieu para explicar a necessidade de harmonia e equilíbrio 
dos poderes republicanos, precisamos que entre os interesses individuais e aqueles da comunidade opere um sistema de contrapesos.

Todavia, como alertam Rancière e Agamben, por motivos e razões distintas, pelo ódio à democratização radical da liberdade ou pelo possível sequestro de uma liberdade individual soberana em um momento de exceção, é a certeza de que esse jogo de forças e de reconhecimento mútuo entre indivíduo e comunidade, ou entre cidadão e estado, entre vontade individual e lei — ainda que ele nunca tenha se universalizado integralmente e para todos os povos e em todos os lugares - que pode estar definitivamente chegando ao fim, e isso sim seria a verdadeira catástrofe civilizatória. Resumidamente, tudo o que conquistamos no último século, com e apesar de duas grandes guerras e dos regimes totalitários, os direitos civis, as experiências democráticas, os direitos humanos, os direitos trabalhistas, os direitos da natureza estão, simplesmente, derretendo com o evidente aquecimento global, com avanço das novas tecnologias sobre a produção e o emprego, com expurgo dos direitos das minorias e, finalmente, com a iminente morte de uma experiência compartilhada de liberdade, aquela forjada na relação entre indivíduo e comunidade.

Finalmente, é preciso recordar Rousseau e recuperar a dimensão política da nossa liberdade. Diferente da liberdade natural — uma experiência independente e conforme os nossos próprios desejos - a liberdade civil foi profundamente transformada pela ideia de pacto social, pela emergência incontornável que somos destinados a uma vida política. Todavia, o que significa isso, liberdade civil? Antes de tudo, uma experiência compartilhada, pois essa liberdade somente pode ser vivida no Estado e em comunidade; depois, trata-se de uma virtude cívica, pois a obediência às leis que a própria vontade instituiu identifica-se, sem qualquer dificuldade, com a autonomia política; mas é também, o mais supremo e legítimo poder, pois vivida pelo povo, nas assembleias e nos diferentes espaços de luta e manifestação, a liberdade civil se sobrepõe à força do governo e a todos os entes particulares; e, o mais fundamental, a liberdade civil é a medida de uma existência autenticamente humana, pois o efetivo gozo dessa liberdade é o que permite ao ser humano ser o que ele é: um ser capaz de dar-se a todos, sem, contudo, submeter-se a ninguém. 


\section{Referências}

AGAMBEN, G. L'invenzione di un'epidemia \& Chiarimenti. In: Quodlibet, 2020. Disponível em: https://www.quodlibet.it/giorgio-agamben-chiarimenti. Acesso em: 15 jun. 2020.

BERLIN, I. Two concepts of liberty. In: BERLIN, I. Four essays on liberty. Oxford: Oxford University Press, 1969.

CANDIOTTO, C. Parrhesia filosófica e ação política: Platão e a leitura de Foucault. Revista de Filosofia Aurora, v. 23, n. 32, p. 31-52, 2011. Disponível em: https://periodicos.pucpr.br/index.php/aurora/article/view/1726/1633. Acesso em: 12 jun. 2020. doi: http://dx.doi.org/10.7213/rfa.v23i32.1726.

CONSTANT, B. De la liberté des Anciens comparée à celle des Modernes. In: CONSTANT, B. Écrits politiques. Paris : Gallimard, 1997. p. 589-619.

LEFORT, C. A Invenção democrática: os limites da dominação totalitária. São Paulo: Brasiliense, 1983.

GRIMAL, P. Os erros da liberdade. Campinas: Papirus, 1990.

MACHIAVELLI, N. "Istorie Fiorentine e altre opere storiche e politiche". In: MACHIAVELLI, N. Opere, a cura di Alessandro Montevecchi. Torino: UTET, 2013.

MACHIAVELLI, N. Discorsi sopra la prima Deca di Tito Livio. Milano: Rizzoli Editore, 2000.

MACHIAVELli, N. O Príncipe. São Paulo: Editora Nova Cultura, 1999. (Coleção Os Pensadores).

LEIA a íntegra do discurso de Bolsonaro na cerimônia de posse no Congresso. São Paulo, 1 de janeiro de 2019. Disponível em: https://www1.folha.uol.com.br/poder/2019/01/leia-aintegra-do-discurso-de-bolsonaro-na-cerimonia-de-posse-no-congresso.shtml. Acesso em: 08 jul. 2019.

PLATON. Oeuvres complètes. Texto grego e tradução francesa. Paris: Les Belles Lettres, 1920. (Collection des Universités de France).

PLATÃO. Protágoras. Trad. Carlos Alberto Nunes. Belém: Ed. UFPA, 2002. (Col. Diálogos).

RANCIÈRE, J. O ódio à democracia. Trad. Mariana Echalar. São Paulo: Boitempo, 2014a.

RANCIÈRE, J. Ainda se pode falar de democracia? (2011). Trad. V. Brito, ed. J. F. Figueira e V. Silva, Ymago. São Paulo, KKYM, 2014b.

ROUSSEAU, J.-J. Do Contrato Social. In: Os Pensadores. Trad. Lurdes Santos Machado. São Paulo: Abril Cultural, 1978.

ROUSSEAU, J.-J. Oeuvres complètes. vols I, II, III, IV e V, Paris: Gallimard: Bibliothèque de la Pléiade, 1964 e 1969. 